\title{
PREVALENCE AND RISK FACTORS OF NEOSPORA CANINUM INFECTION IN OVINE FLOCKS OF CENTRAL-WESTERN MEXICO
}

\author{
Jesús Manuel Romo-Gallegos ${ }^{1}$, Carlos CRuZ-VÁZquez ${ }^{1 *}$, Leticia MedinA-EsParzA ${ }^{1}$, \\ Miguel RAMOS-PARRA ${ }^{1}$ and Dora ROMERO-SALAS ${ }^{2}$ \\ ${ }^{1}$ Technological Institute of the Llano Aguascalientes, Km. 18 carretera Aguascalientes, \\ San Luis Potosí, El Llano, 20330 Aguascalientes, Mexico; ${ }^{2}$ Faculty of Veterinary \\ Medicine and Zootechnics, University of Veracruz, Veracruz, Mexico
}

(Received 6 July 2018; accepted 20 November 2018)

This study, carried out in 13 sheep flocks of central-western Mexico, aimed to identify the prevalence of anti- $N$. caninum antibodies, to develop a risk analysis of the infection and to estimate the prevalence of parasite DNA in blood. A total of 368 serum and blood samples were subjected to ELISA and PCR tests, respectively, and the association between the prevalence of antibodies and some management factors was estimated. The overall prevalence of anti-N. caninum antibodies was 13.5\% [50/368; 95\% confidence interval (CI) 10-17], ranging from 2.7 to $90 \%$ per flock, and $92 \%$ of the farms had seropositive animals. In ewes the prevalence was $14 \%(48 / 348,95 \%$ CI $10-17)$ and in rams $10 \%(2 / 20 ; 95 \%$ CI $1-$ $33)$. The mean prevalence of Neospora DNA in blood was $27 \%(99 / 368,95 \%$ CI 22-31), implying a range between 16 and $82 \%$. In rams, the prevalence was $5 \%$ $(1 / 2095 \%$ CI $2-26)$, while in ewes it was $28 \%(98 / 348,95 \%$ CI $23-33)$. The agreement between the tests was $k=0.19$. The presence of other domestic animal species in the farms [odds ratio (OR) 4.4] and the consumption of placental debris, fetuses and stillborn lambs by dogs living in the farms (OR 5.8) were demonstrated to be risk factors.

Key words: Neospora caninum, sheep, prevalence, DNA, risk factors

Neospora caninum (Apicomplexa, Sarcocystidae) is an obligate intracellular protozoan parasite of cosmopolitan nature that mainly affects livestock, in which it can cause abortion (Dubey and Schares, 2011). The parasite has a heteroxenous life cycle, in which the domestic dog and the coyote act as the main definitive hosts (McAllister et al., 1998; Gondim et al., 2004), although the Australian dingo and the grey wolf of North America might also play this role (King et al., 2010; Dubey et al., 2011). In addition to livestock, a broad range of animals can act as intermediate hosts, including small ruminants (Dubey and Scha-

*Corresponding author; E-mail: cruva18@yahoo.com.mx;

Phone/Fax: 0052 (449) 962-1100 
res, 2011). Ruminants are exposed to horizontal infection when consuming water and food contaminated with oocysts excreted by the definitive host, while an infected female can transmit the parasite to the fetus through the placenta; vertical transmission is considered a major route of infection in these animals (Dubey et al., 2007). Sheep are affected by N. caninum, and the infection can cause reproductive problems and abortions, although on a smaller scale than in cattle (Dubey and Schares, 2011; González-Warleta et al., 2014). In a recent study carried out under experimental conditions, it has been shown that the gestational stage of sheep is a major factor in determining the course of infection (ArranzSolís et al., 2015), while vertical transmission during natural infection can be significant (Filho et al., 2017). The detection of DNA in the brain tissue of fetuses has also been documented and associated with abortions (Masala et al., 2007; Howe et al., 2012; Moreno et al., 2012). The presence of anti- $N$. caninum antibodies and some risk factors associated with it has been documented in several regions of the world, and seroprevalence has been reported to range between 0.6\% and 64.2\% (Dubey et al., 2007; Dubey and Schares, 2011; Liu et al., 2015; Gazzonis et al., 2016; Cerqueira-Cézar et al., 2017; Wang et al., 2018). In Mexico, there is limited epizootiological information about ovine neosporosis, with only a single study in which a seroprevalence of $5.5 \%$ has been found and the prevalence of parasite DNA in the blood was 25\% (Castañeda-Hernández et al., 2014).

Therefore, the present work was carried out in different sheep flocks of central-western Mexico, with the objectives to document the prevalence of anti$N$. caninum antibodies, to develop a risk analysis of the infection and to estimate the prevalence of parasite DNA in the blood of sheep.

\section{Materials and methods}

\section{Study site}

The study was carried out in the Altos Norte region of Jalisco, located in central-western Mexico. The following municipalities were included: Encar-

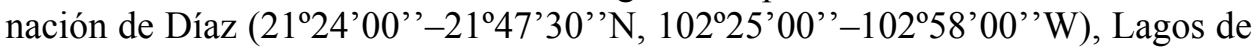
Moreno $\left(21^{\circ} 12^{\prime}-21^{\circ} 55^{\prime} \mathrm{N}, 101^{\circ} 32^{\prime}-102^{\circ} 10^{\prime} \mathrm{W}\right)$, Ojuelos de Jalisco $\left(21^{\circ} 33^{\prime}\right.$ $\left.22^{\circ} 02^{\prime} \mathrm{N}, 101^{\circ} 02^{\prime}-101^{\circ} 53^{\prime} \mathrm{W}\right)$, San Diego de Alejandría $\left(20^{\circ} 52^{\prime}-21^{\circ} 02^{\prime} \mathrm{N}\right.$, $\left.101^{\circ} 54^{\prime}-102^{\circ} 05^{\prime} \mathrm{W}\right)$ and San Juan de los Lagos $\left(21^{\circ} 04^{\prime}-21^{\circ} 24^{\prime} \mathrm{N}, 102^{\circ} 06^{\prime}-\right.$ $102^{\circ} 10^{\prime} \mathrm{W}$ ). The region is located between 1750 metres above sea level (San Juan de los Lagos) and 2220 metres above sea level (Ojuelos de Jalisco), it has a temperate to semi-warm climate with summer rains and an average annual rainfall between $474 \mathrm{~mm}$ (Ojuelos de Jalisco) and $750 \mathrm{~mm}$ (San Juan de los Lagos), while the average annual temperature in the region is $18.5^{\circ} \mathrm{C}$ with a minimum of $17.1^{\circ} \mathrm{C}$ (Ojuelos de Jalisco) and a maximum of $19.4^{\circ} \mathrm{C}$ (Encarnación de Díaz). 


\section{Sheep flocks}

Thirteen sheep farms distributed in the five municipalities mentioned above participated in the study. The farms are dedicated to meat production, keeping females of undefined biotype (crossbred) that are covered with purebred rams (mainly from breeds such as the Dorper, Blackbelly, Kathadin and Pelibuey); reproductive management is intensive with scheduled births throughout the year. The animals are kept in confinement in a natural environment, in pens with concrete floor, equipped with collective feeders and drinkers, and the diet consists of corn silage and hay of oats or wheat. A disease prevention programme is applied and the flocks are certified as brucellosis free in all cases. The Committee on the Use and Care of Animals of the Instituto Tecnológico El Llano Aguascalientes and the farm owners approved this project (ITEL-CUCA 015/17), and adequate veterinary care was provided to all animals under study.

\section{Questionnaire}

A written questionnaire was given to the farm owners with the objective of recording the management practices, which included identification data of the farm as well as the animals (sex, age), the presence of other domestic animals on the farm, reproductive management, frequency of abortions and stillbirths, management of placental and fetal waste, presence of dogs in the farm, sightings or attacks of coyotes, and origin of the drinking water.

\section{Samples}

For this study, 368 blood samples were collected from a total of 263 ewes, 85 primiparous ewe lambs and 20 rams. The samples were taken by puncture of the jugular vein using new vacutainer equipment: one sample was taken into a tube with anticoagulant (EDTA) and another into a tube without it. In the laboratory, serum was obtained by centrifugation $(1000 \times g$ for $15 \mathrm{~min})$, and stored in polystyrene microtubes at $-20^{\circ} \mathrm{C}$. The blood samples with anticoagulant were stored at $-40{ }^{\circ} \mathrm{C}$ until later use.

\section{ELISA test}

Serum samples were subjected to enzyme-linked immunosorbent assay (ELISA) to determine $N$. caninum-specific IgG using the commercial package Neospora caninum antibody test kit ruminants (IDEXX Laboratories, Inc., Westbrook, ME, USA), with $100 \%$ sensitivity and $98.9 \%$ specificity according to the manufacturer. The sera were tested pairwise at 1:10 dilution, and the cut-off point determined to regard a sample as positive was established at $\geq 0.50$. 


\section{PCR probe}

This probe was developed as described by Castañeda-Hernández et al. (2014). DNA extraction from blood samples was done using a commercial package (Ultraclean DNA BloodSpin, MOBIO Laboratories, Inc.), and DNA amplification was performed using the primers NF1, NS2, NR1 and SR1 (Ellis et al., 1999), with appropriate controls. All samples were tested twice, considering positive only those which showed the amplification of a product with the size of 146 base pairs.

\section{Data analysis}

The seroprevalence as well as the prevalence of parasite DNA in the blood were calculated, identifying the animals that were positive in both tests and calculating the Kappa coefficient to determine the agreement between the two tests $(\mathrm{P}<0.05)$. The association between the serological status and the possible risk factors (information collected in the questionnaires) was done by calculating the Odds Ratio (OR), where values greater than 1 indicated an association. The calculation was subjected to $\chi^{2}$ test with Yates correction $(\mathrm{P}<0.05)$. All procedures were performed using the Epi Info 3.5.1 software package.

\section{Results}

In the population under study the overall prevalence of anti- $N$. caninum antibodies was $13.5 \%(50 / 368 ; 95 \%$ CI $10-17)$, ranging from 2.7 to $90 \%$ per flock, and $92 \%$ of the farms had seropositive animals (Table 1). In ewes the prevalence was $15 \%(39 / 263 ; 95 \%$ CI $10-19)$ and in primiparous ewe lambs it was $11 \%(9 / 85 ; 95 \%$ CI $5-19)$. Thus, the prevalence in females was $14 \%$ $(48 / 348 ; 95 \%$ CI $10-17)$ and in rams $10 \%(2 / 20 ; 95 \%$ CI $1-33)$. Neospora DNA in blood showed a mean prevalence of $27 \%(99 / 368$; $95 \%$ CI $22-31)$, with a single farm where no PCR-positive animals were found. The prevalence among flocks varied from 16 to $82 \%$ (Table 1$)$. The prevalence was 5\% (1/20 95\% CI $2-26)$ in rams, $19 \%(16 / 85 ; 95 \%$ CI 11-29) in primiparous ewe lambs and $31 \%$ $(82 / 263 ; 95 \%$ CI $25-37)$ in ewes. Thus, the prevalence in females was $28 \%$ (98/348; 95\% CI 23-33). The agreement between the ELISA and the PCR test was $k=0.19$ (95\% CI 9-29). The presence of other domestic animal species in the farms was identified as a risk factor (OR 4.4; 95\% CI 1.53-12.58, $\mathrm{P}<0.05$ ), as well as the consumption of placental debris, fetus and stillborn lambs by dogs living in the farms (OR 5.8; 95\% CI 3.06-11.09, $\mathrm{P}<0.05$ ). However, the presence of dogs (OR 2.2; 95\% CI 0.29-17.5) did not have a statistically significant association $(\mathrm{P}>0.05)$. It was not possible to identify an association between prevalence and other factors considered in the risk analysis, because the farms presented similar management conditions. 
Table 1

Prevalence of anti- $N$. caninum antibodies and DNA detection in the blood in sheep flocks of the Altos Norte region of Jalisco, Mexico

\begin{tabular}{|c|c|c|c|c|c|c|c|c|}
\hline $\begin{array}{l}\text { Farm } \\
\text { no. }\end{array}$ & Municipality & $\begin{array}{c}\text { Number } \\
\text { of sheep } \\
\text { (n) }\end{array}$ & $\begin{array}{l}\text { Sero- } \\
\text { positive } \\
\text { sheep } \\
\text { (n) }\end{array}$ & $\begin{array}{c}\text { Prevalence } \\
(\%)\end{array}$ & $\begin{array}{c}95 \% \\
\text { CI }\end{array}$ & $\begin{array}{l}\text { PCR- } \\
\text { positive } \\
\text { sheep } \\
\text { (n) }\end{array}$ & $\begin{array}{c}\text { Prevalence } \\
(\%)\end{array}$ & $\begin{array}{c}95 \% \\
\mathrm{CI}\end{array}$ \\
\hline 1 & Lagos & 31 & 3 & 10 & $2-26$ & 8 & 26 & $12-44$ \\
\hline 2 & Lagos & 29 & 19 & 66 & $45-81$ & 21 & 72 & $52-86$ \\
\hline 3 & Lagos & 31 & 4 & 13 & 4-30 & 8 & 26 & $12-44$ \\
\hline 4 & Lagos & 31 & 0 & 0 & 0 & 0 & 0 & 0 \\
\hline 5 & Encarnación & 36 & 1 & 3 & $0.1-16$ & 6 & 17 & $6-33$ \\
\hline 6 & Encarnación & 14 & 1 & 7 & $0.3-35$ & 5 & 36 & $13-64$ \\
\hline 7 & Encarnación & 31 & 2 & 6 & $1-22$ & 7 & 23 & $10-41$ \\
\hline 8 & Encarnación & 11 & 10 & 90 & $57-99$ & 9 & 82 & $47-96$ \\
\hline 9 & San Juan & 31 & 2 & 6 & $1-22$ & 9 & 29 & $14-48$ \\
\hline 10 & San Juan & 31 & 4 & 13 & $4-30$ & 7 & 23 & $10-41$ \\
\hline 11 & Ojuelos & 31 & 1 & 3 & $0.1-18$ & 5 & 16 & $6-34$ \\
\hline 12 & Ojuelos & 32 & 2 & 6 & $1-22$ & 7 & 22 & $9-40$ \\
\hline 13 & San Diego & 29 & 1 & 3 & $0.1-19$ & 7 & 24 & $11-43$ \\
\hline Total & & 368 & 50 & 13.5 & $10-17$ & 99 & 27 & $22-31$ \\
\hline
\end{tabular}

$\mathrm{CI}=$ confidence interval

\section{Discussion}

The epizootiology of $N$. caninum infection in sheep, as well as its clinical and economic importance, are not completely known. However, there are several reports documenting a wide geographical distribution of ovine neosporosis, as well as its ability to cause reproductive failures, although these are not of the same magnitude as in dairy cattle (Dubey and Schares, 2011; Howe et al., 2012; González-Warleta et al., 2014; Arranz-Solís et al., 2015). The prevalence of anti$N$. caninum antibodies identified in the present study was $13.5 \%$, implying seropositive animals in $92 \%$ of the farms; these results contrast with those reported in the state of Aguascalientes, Mexico, where the prevalence was only $5.5 \%$ with $61 \%$ of the flocks infected (Castañeda-Hernández et al., 2014). This difference can be due to several causes, among them to differences between the diagnostic tests, sheep population density (which is higher in the region of this study than in Aguascalientes), as well as the presence of dairy cattle and the management practices used. There is no information on the prevalence of neosporosis in dogs in the region where this study was done; however, except for one farm, all the herds included in the study had dogs permanently domiciled there and having access to pens and feed stores. Prevalence can change from one region to another as it does from herd to herd, so the contrast found is not surprising. For example, in Brazil 
several studies using the indirect immunofluorescence test have identified a prevalence as low as $1.8 \%$ (Soares et al., 2009), and as high as $64.2 \%$ (Tembue et al., 2011). Studies in other countries using the ELISA technique have reported results ranging from 2.2\% in Australia (Bishop et al., 2010) up to $57 \%$ in Galicia, Spain (Panadero et al., 2010). Recently, it has been observed that under experimental conditions $N$. caninum can be efficiently transmitted vertically to offspring, causing abortion or premature birth as well as weak or clinically healthy offspring (Arranz-Solís et al., 2015), while in natural infections Filho et al. (2017) observed that seroconversion may have an incidence as high as $62.2 \%$. These data suggest that sheep can develop both a chronic infection and be exposed to a horizontal infection. In addition, the authors also observed vertical transmission with a frequency of $11 \%$. In this study we found a prevalence of $27 \%$ for Neospora DNA in the blood, while the seroprevalence was $13.5 \%$, and the agreement between these two tests was $19 \%$. These results are similar to those found in flocks of Aguascalientes, Mexico (Castañeda-Hernández et al., 2014). However, taking into account what was observed by Filho et al. (2017), this seroprevalence may also be underestimated. Howe et al. (2012) suggest that the presence of $N$. caninum DNA in the blood of seronegative animals may be related to a recent infection or to immune tolerance. In cattle, it has been observed that the detection of DNA in the blood is irregular in seropositive cows, and seronegative animals can be chronically infected. In both scenarios, pregnant cows can transmit the parasite to their offspring or abort (Okeoma et al., 2005; Frössling et al., 2005; Santos et al., 2010). A seropositive ram was identified with the presence of parasite DNA in the blood; however, this finding has no clinical or epizootiological significance as has already been documented by other authors (Syed-Hussain et al., 2013).

Dogs as definitive hosts of $N$. caninum play an important role in the epizootiology of the infection; however, they have not always been identified as a risk factor for infection (Gazzonis et al., 2016; Cerqueira-Cézar et al., 2017). This is consistent with our results. However, it has been identified as a risk factor if dogs have access to and consume placental debris, fetuses and stillborn lambs, which is a common habit in the farms included in the study since dogs roam freely through the facilities having access to these materials and the possibility to defecate anywhere in the farm, by which they can contaminate water and feed with unsporulated oocysts. In addition, these farms keep sheep in confinement. It has been reported that if sheep are kept in confinement, this can increase the possibilities of transmission from dogs (Corbellini et al., 2006; Dubey and Schares, 2011). The presence of other domestic animal species in the farms under study was identified as a risk factor for $N$. caninum infection. These species include dairy cattle, chickens and cats, as well as wildlife such as rats, mice, squirrels, hares and birds. The presence of different animal species which may act as intermediate hosts of $N$. caninum can represent a risk as soon as they are candi- 
dates to be preyed upon by the definitive host, mainly dogs and coyotes (Dubey et al., 2007; de Barros et al., 2018). The presence of coyotes in the region of this study is common, although their incursions into the farms are rare. However, it is possible that they consume small mammals and birds that inhabit the farms and the fields of nearby feed crops. Coyotes are widely distributed in Mexico and they have no predator except humans (Hernández and Laundré, 2014). These findings confirm the need to prevent the contamination of the drinking water and feed consumed by ruminants with canine faeces (McAllister, 2016), as well as to limit the access of canines to placental debris, fetus, stillborn lambs, and wild animals.

In conclusion, the present study shows that $N$. caninum infection in sheep of central-western Mexico is important and can be associated with reproductive losses in the flocks. Risk factors identified should be the guide to prevent horizontal infection in sheep flocks and consequently to reduce vertical transmission.

\section{Acknowledgements}

The authors thank the sheep farmers of the region under study for their collaboration.

\section{References}

Arranz-Solís, D., Benavides, J., Regidor-Cerrillo, J., Fuertes, M., Ferre, I., Del Ferreras, M., Collantes-Fernández, E., Hemphill, A., Perez, V. and Ortega-Mora, L. M. (2015): Influence of the gestational stage on the clinical course, lesional development and parasite distribution in experimental ovine neosporosis. Vet. Res. 46, 19.

Bishop, S., King, J., Windsor, P., Reichel, M. P., Ellis, J. and Slapeta, J. (2010): The first report of ovine cerebral neosporosis and evaluation of Neospora caninum prevalence in sheep in New South Wales. Vet. Parasitol. 170, 137-142.

Castañeda-Hernández, A., Cruz-Vázquez, C. and Medina-Esparza, L. (2014): Neospora caninum: Seroprevalence and DNA detection in blood of sheep from Aguascalientes, Mexico. Small Rum. Res. 119, 182-186.

Cerqueira-Cézar, C. K., Calero-Bernal, R., Dubey, J. P. and Gennari, S. M. (2017): All about neosporosis in Brazil. Braz. J. Vet. Parasitol. 26, 253-279.

Corbellini, L. G., Smith, D. R., Pescador, C. A., Schmitz, M., Correa, A., Steffen, D. J. and Driemerier, D. (2006): Herd-level risk factors for Neospora caninum seroprevalence in dairy farms in southern Brazil. Prev. Vet. Med. 74, 130-141.

de Barros, L. D., Miura, A. C., Minutti, A. F., Vidotto, O. and Garcia, J. L. (2018): Neospora caninum in birds: A review. Parasitol. Int. 67, 397-402.

Dubey, J. P. and Schares, G. (2011): Neosporosis in animals - the last five years. Vet. Parasitol. 180, 90-108.

Dubey, J. P., Jenkins, M. C., Rajendran, C., Miska, K., Ferreira, L. R., Martins, J., Kwok, O. C. H. and Choudhary, S. (2011): Gray wolf (Canis lupus) is a natural definitive host for Neospora caninum. Vet. Parasitol. 27, 382-387.

Dubey, J. P., Schares, G. and Ortega-Mora, L. M. (2007): Epidemiology and control of neosporosis and Neospora caninum. Clin. Microbiol. Rev. 120, 323-367. 
Ellis, J. T., McMillan, D., Ryce, C., Payne, S., Atkinson, R. and Harper, P. A. W. (1999): Development of a single tube nested polymerase chain reaction assay from the detection of $\mathrm{Ne}$ ospora caninum DNA. Int. J. Parasitol. 29, 1589-1596.

Filho, P. C. G. A., Oliveira, J. M. G., Andrade, M. R., Silva, J. G., Kim, P. C. P., Almeida, J. C., Porto, W. and Mota, R. A. (2017): Incidence and vertical transmission rate of Neospora caninum in sheep. Comp. Immunol. Microbiol. Infect. Dis. 52, 19-22.

Frössling, J., Uggla, A. and Björkman, C. (2005): Prevalence and transmission of Neospora caninum within infected Swedish dairy herds. Vet. Parasitol. 18, 209-218.

Gazzonis, A. L., Alvarez Garcia, G., Zanzani, S. A., Ortega Mora, L. M., Invernizzi, A. and Manfredi, M. T. (2016): Neospora caninum infection in sheep and goats from north-eastern Italy and associated risk factors. Small. Rum. Res. 140, 7-12.

Gondim, L. F. P., McAllister, M. M., Pitt, W. C. and Zemlicka, D. E. (2004): Coyotes (Canis latrans) are definitive hosts of Neospora caninum. Int. J. Parasitol. 34, 159-161.

González-Warleta, M., Castro-Hermida, J. A., Regidor-Cerrillo, J., Benavides, J., Álvarez-García, G., Fuertes, M., Ortega-Mora, L. M. and Mezo, M. (2014): Neospora caninum infection as a cause of reproductive failure in a sheep flock. Vet. Res. $45,88$.

Hernández, L. and Laundré, J. W. (2014): Los coyotes en México. In: Valdez, R. and Ortega, S. J. A. (eds) Ecología y Manejo de Fauna Silvestre en México [in Spanish]. Colegio de Posgraduados, México. pp. 271-294.

Howe, L., Collett, M. G., Pattison, R. S., Marshall, J., West, D. M. and Pomroy, W. E. (2012): Potential involvement of Neospora caninum in naturally occurring ovine abortions in New Zealand. Vet. Parasitol. 185, 64-71.

King, J. S., Slapeta, J., Jenkins, D. J., Al-Qassab, S. E., Ellis, J. T. and Windsor, P. A. (2010): Australian dingoes are definitive hosts of Neospora caninum. Int. J. Parasitol. 40, 945-950.

Liu, Z. K., Li, J. Y. and Pan, H. (2015): Seroprevalence and risk factors of Toxoplasma gondii and Neospora caninum infections in small ruminants in China. Prev. Vet. Med. 118, 488-492.

Masala, G., Porcu, R., Daga, C., Denti, S., Canu, G., Patta, C. and Tola, S. (2007): Detection of pathogens in ovine and caprine abortion samples from Sardinia, Italy, by PCR. J. Vet. Diag. Inv. 19, 96-98.

McAllister, M. M. (2016): Diagnosis and control of bovine neosporosis. Vet. Clin. North Am. Food Anim. Pract. 32, 443-463.

McAllister, M. M., Dubey, J. P., Lindsay, D. S., Jolley, W. R., Wills, R. A. and McGuire, A. M. (1998): Dogs are definitive hosts of Neospora caninum. Int. J. Parasitol. 28, 1473-1478.

Moreno, B., Collantes-Fernández, E., Villa, A., Navarro, A., Regidor-Cerillo, J. and Ortega-Mora, L. M. (2012): Occurrence of Neospora caninum and Toxoplasma gondii infections in ovine and caprine abortions. Vet. Parasitol. 187, 312-318.

Okeoma, C. M., Stowell, K. M., Williamson, N. B. and Pomroy, W. E. (2005): Neospora caninum: quantification of DNA in the blood of naturally infected aborted and pregnant cows using real-time PCR. Vet. Parasitol. 110, 48-55.

Panadero, R., Painceira, A., López, C., Vázquez, L., Paz, A., Díaz, P., Dacal, V., Cienfuegos, S., Fernández, G., Lago, N., Díez-Baños, P. and Morrondo, P. (2010): Seroprevalence of Toxoplasma gondii and Neospora caninum in wild and domestic ruminants sharing pastures in Galicia (Northwest Spain). Res. Vet. Sci. 88, 111-115.

Santos, S. L., de Souza Costa, K., Gondim, L. Q., da Silva, M. S., Uzeda, R. S., Abe-Sandes, K. and Gondim, L. F. (2010): Investigation of Neospora caninum, Hammondia sp., and Toxoplasma gondii in tissues from slaughtered beef cattle in Bahia, Brazil. Parasitol. Res. 106, 457-461.

Soares, H. S., Ahid, S. M., Becerra, A. C., Pena, H. F., Dias, R. A. and Gennari, S. M. (2009): Prevalence of anti-Toxoplasma gondii and anti-Neospora caninum antibodies in sheep from Mossoró, Rio Grande do Norte, Brazil. Vet. Parasitol. 160, 211-214. 
Syed-Hussain, S. S., Howe, L., Pomroy, W. E., West, D. M., Smith, S. L. and Williamson, N. B. (2013): Detection of Neospora caninum DNA in semen of experimental infected rams with no evidence of horizontal transmission in ewes. Vet. Parasitol. 197, 534-542.

Tembue, A. A. S. M., Ramos, R. A. N., Sousa, T. R., Albuquerque, A. R., Costa, A. J., Meunier, I. M. J., Faustino, M. A. G. and Alves, L. C. (2011): Serological survey of Neospora caninum in small ruminants from Pernambuco State, Brazil. Rev. Bras. Parasitol. Vet. 20, 246-248.

Wang, S., Li, L., Lu, Y., Zhang, H., Xie, Q. and Zhang, Z. (2018): Seroprevalence and risk factors of Neospora caninum infection among domestic sheep in Henan province, central China. Parasite 25, 15. 